\title{
Differential Preference of Wintering Mule Deer for Accessions of Big Sagebrush and for Black Sagebrush
}

\author{
BRUCE L. WELCH, E. DURANT MCARTHUR, AND JAMES N. DAVIS
}

\begin{abstract}
Free-roaming mule deer showed significant differential preference for accessions of big sagebrush (Artemisia tridentata) grown in a uniform garden. Mule deer also selectively preferred certain accessions of black sagebrush $(A$. nova). The role of monoterpenoids (essential or volatile oils) in determining preference among accessions and taxa of Artemisia - the sagebrushes-and the role of sagebrush as a food of starvation is discussed.
\end{abstract}

Differential preference of mule deer for populations and individual plants of big sagebrush (Artemisia tridentata) has been noted by several workers (Smith 1950; Plummer et al. 1968; Winward 1970; Hanks et al. 1973; Stevens and McArthur 1974; Winward and Tisdale 1977; Willms et al. 1979; and McArthur et al. 1979). Few, however, have quantified their observations. Hanks et al. (1973), Sheehy (1975), and Scholl et al. (1977) did quantify their observed preferential differences. Of these workers, only Sheehy (1975) made statistical comparisons. He found that mule deer significantly preferred some sagebrush taxa over others. Preference of wintering mule deer for accessions of big sagebrush is one of several key characteristics being considered in our selecting and breeding program (Wclch and McArthur 1979a). Therefore, we undertook this study to expand our knowledge base concerning mule deer preference for accessions of big sagebrush (A. tridentata) and for black sagebrush (A. nova) grown in a uniform garden.

\section{Materials and Methods}

From a uniform shrub ${ }^{1}$ garden located at the Gordon Creek wildlife management area near Helper, Utah, 10 accessions of big sagebrush (Artemisia tridentata) and four accessions of black sagebrush (Artemisia nova) were chosen to determine differential preference by free-roaming, wintering mule deer. The accessions (plant material from a specific site) were transplanted onto the garden as wildlings from various Intermountain areas (Table 1). For each accession of big sagebrush, 10 plants were randomly selected. Plants were approximately the same age (planted 1968-1971). Twenty annual leaders per plant were measured to the nearest centimcter during mid-Octobcr 1977 and 1978. The leaders were selected at random over the entire crown of the plants. The 20 measurements per plant were used to arrive at a mean annual leader length (before browsing) for each plant. After the winter, and before spring growth, the plants were remeasured in the same manner as they were in October and a mean annual leader length

\footnotetext{
Authors are research plant physiologist and research geneticist with the U.S. Dep. Agr. Forest Service, Intermountain Forest and Range Experiment Station, Shrub Sciences Laboratory, Provo, Utah 84601 ; and wild life research biologist with the Utah Division of Wildlife Resources, Shrub Sciences Laboratory, Provo, Utah 84601.

Manuscript received March 4, 1980

'The uniform shrub garden at the Gordon Creek wildlife management area near Helper, Utah, is cooperatively maintaincd by the Utah State Division of Wildlife Resources (W-82-R) and the Intermountain Forest and Range Experiment Station.
}

Table 1. Locations of $\mathbf{1 0}$ accessions of big sagebrush (Artemisia tridentata) and four accessions of black sagebrush (Artemisia nova) used to determine differences in preference of wintering wild mule deer. These accessions were grown on a uniform garden near Helper, Utah.

\begin{tabular}{llll}
\hline \hline Species & Subspecies & Accessions & County and State \\
\hline tridentata & vaseyana & Hobble Creek & Utah, Utah \\
& & Spanish Valley & Grand, Utah \\
& & Indian Peaks & Beaver, Utah \\
& & Milford & Beaver, Utah \\
& & Monticello & San Juan, Utah \\
tridentata & \multirow{2}{*}{ tridentata } & Indianola & Sanpete, Utah \\
& & Loa & Wayne, Utah \\
& & Dove Creek & Dolores, Colorado \\
& & Marysvale & Piute, Utah \\
tridentata & \multirow{2}{*}{ wyomingensis } & Trough Springs & IIumboldt, Nevada \\
nova & & Lund & Iron, Utah \\
& & Manti & Sanpete, Utah \\
& & Pioche & Lincoln, Nevada \\
& & Pine Valley & Millard, Utah \\
\hline
\end{tabular}

(after browsing) was determined. Percent used was calculated by dividing the mean leader length after browsing by the mean leader length before browsing, and then multiplied by 100 . This method of measuring leader length contained a precision error term of $4 \%$. During the first year, we had the occasion to visit the shrub garden before the start of winter (December 12, 1977). Significant browsing of the big sagebrush was noted. We remeasured the big sagebrush in the manner described above so we could determine the amount of big sagebrush eaten before winter's onslaught.

For black sagebrush, 10 plants per accession were analyzed by the ocular method (National Academy of Sciences 1962) to estimate deer use. This was done only in the winter of 1978 .

A completely random-designed analysis of variance was used to detect significant effects due to accessions. Hartley's multiple range test was used to compare accession means (Snedecor and Cochran 1967). A $t$-test with paired observations was used to compare winters (Snedecor and Cochran 1967).

\section{Results}

There was a significant difference in the use of big sagebrush between the winters of 1977 and 1978. This prevented the pooling of data for the two winters. In general, there was a reduction of about $10 \%$ in the use of the 10 accessions of big sagebrush for the winter of 1978 (Table 2). This reduction was not uniform among the accessions, i.e., Spanish Valley and Marysvale accessions were down by $19 \%$. The Dove Creek accession was browsed more in 1978 than in 1977 (Table 2). This accession was the tallest of all accessions in the garden. 
Table 2. The winter preference of wild mule deer for 10 accessions of big sagebrush (Artemisia tridentata) grown on a uniform garden near Helper, Utah.

\begin{tabular}{|c|c|c|c|}
\hline \multicolumn{2}{|c|}{ Winter of 1977} & \multicolumn{2}{|c|}{ Winter of 1978} \\
\hline Accession & $\%$ used & Accession & $\%$ used \\
\hline Hobble Creek & $84^{a} *$ & Hobble Creek & $74^{a_{1}}$ \\
\hline Spanish Valley & $73^{\mathrm{a}}$ & Monticello & $59^{\mathrm{ab}}$ \\
\hline Monticello & $63^{\mathrm{ab}}$ & Spanish Valley & $54^{\mathrm{ab}}$ \\
\hline Indian Peaks & $59^{\mathrm{b}}$ & Dove Creek & $50^{\mathrm{b}}$ \\
\hline Milford & $58^{\mathrm{b}}$ & Indian Peaks & $47^{b}$ \\
\hline India nola & $47^{b c}$ & Milford & $45^{\mathrm{bc}}$ \\
\hline Dove Creek & $46^{\mathrm{bcd}}$ & Indianola & $40^{\mathrm{bc}}$ \\
\hline Loa & $33^{\text {cd }}$ & Loa & $24^{\text {cd }}$ \\
\hline Trough Springs & $29^{d}$ & Marysvale & $12^{\mathrm{d}}$ \\
\hline Marysvale & $19^{d}$ & Trough Springs & $10^{d}$ \\
\hline
\end{tabular}

'Values sharing the same letter superscript are not significantly different at the $5 \%$ level.

Some accessions of big sagebrush were preferred by mule deer over others (Table 2). The accessions were grouped similarly in both years despite the significant differences between winters. Hobble Creek accession was the most preferred accession of big sagebrush ( $84 \%$ and $74 \%$ used), although not significantly preferred over Spanish Valley and Monticello accessions. Accessions from Loa, Trough Springs, and Marysvale were the least preferred by the wintering mule deer.

Our December 12, 1977, measurements showed considerable pre-winter mule deer use of several accessions of big sagebrush (Table 3). Better than 50\% of the current year's growth of four accessions (Hobble Creek, Indian Peaks, Milford, and Monticello), had been eaten before the start of winter (Table 3 ).

\section{Table 3. Amount of wild mule deer use on 10 accessions of big sagebrush (Artemisia tridentata) before the start of winter. Accessions were grown on a uniform garden located at Helper, Utah.}

\begin{tabular}{lc}
\hline \hline Accession & \% used as of December 12, 1977 \\
\hline Hobble Creek & 58.7 \\
Indian Peaks & 53.1 \\
Milford & 52.2 \\
Monticello & 51.8 \\
Spanish Valley & 39.5 \\
Indianola & 14.2 \\
Dove Creek & 10.3 \\
Trough Springs & 8.8 \\
Marysvale & 6.6 \\
Loa & 0.0 \\
\hline
\end{tabular}

As with big sagebrush, some accessions of black sagebrush were preferred over others by mule deer (Table 4). The accessions va ried in use from zero (Lund accession) to $60 \%$ (Pine Valley). Deer removed $2.2 \%$ of the Manti accession current year's growth. The Pioche accession had $19.7 \%$ of the current-year growth removed.

\section{Discussion}

Winter effect on the differential preference of free-roaming wintering mule deer for 10 accessions of big sagebrush was nonsignificant for changing the array clusters of the accessions. Some movement within the arrays occurred between the winters, but for

Table 4. Preference of wintering wild mule deer for four accessions of black sagebrush (Artemisia nova) grown on a uniform garden near Helper, Utah, winter of 1978 .

\begin{tabular}{lc}
\hline \hline Accession & $\%$ used \\
\hline Lund & 0.0 \\
Manti & 2.2 \\
Pioche & 19.7 \\
Pine Valley & 60.0 \\
\hline
\end{tabular}

the most part, these changes were of the magnitude of one position, except for the Dove Creek accession. None of the changes were from one group of significance to another. This differential preference of winter mule deer for big sagebrush has been observed in the field by a number of workers (Smith 1950; Plummer et al. 1968; Winward 1970; Brunner 1972; Hanks et al. 1973; Stevens and McArthur 1974; Sheehy 1975; Scholl et al. 1977; Winward and Tisdale 1977; Willms et al. 1979; McArthur et al. 1979; and Welch and McArthur 1979a). We will, in the near future, attempt to combine the high digestibility, high crude protein, and fast growth rate characteristics of the Dove Creek accession with the high preference of the Hobble Creek accession (Welch and McArthur 1979a; Welch and McArthur 1979b; Welch and Pederson 1982). Hopefully, this will result in a nutritionally superior strain of big sagebrush for use on mule deer winter ranges.

Some workers believe that big sagebrush is consumed by mule deer in the late winter or "very" early spring (Nagy et al. 1964; Nagy and Tengerdy 1968; Dietz and Nagy 1976; and Nagy 1979). The implication given is that big sagebrush is a starvation food, that is, big sagebrush is eaten only when nothing else is available. Our results show that mule deer consumed $58.7 \%$ of the current year's growth of the Hobble Creek accession, $53.1 \%$ for Indian Peaks, $52.2 \%$ for Milford, and $51.8 \%$ for Monticello-before the onset of winter, December 12, 1977 (Table 3). These results agree with the observations made by Welch and Andrus (1977). They found that 2 days after mule deer arrived on a winter range near Richmond, Utah, the only shrubs heavily browsed were vasey big sagebrush (A. tridentata ssp. vaseyana), the hips of woods rose (Rosa woodsii), and sweetbrier rose ( $R$. eglanteria). Black chokecherry (Prunus virginiana melanocarpa) and antelope bitterbrush (Purshia tridentata) were not heavily browsed until a month later. Also, Medin (1980) found during a 5-year dietary study of wintering mule deer in north central Colorado that big sagebrush made up $5 \%$ of the fall diet $(\max .27 \%), 31 \%$ of the winter diet $(\max .75 \%)$, and $14 \%$ of the spring diet (max. $56 \%$ ). It was noted by Medin and Anderson (1979) that during this 5-year period, a wide variety of forages was almost continuously available. The deer did not have to eat the big sagebrush. Others also have reported non-starvation use of big sagebrush by mule deer (Julander 1955; Mackie 1970; Constan 1972). Kufeld et al. (1973 summary), indicates some yearround use of big sagebrush by mule deer with heaviest use occurring during the winter.

It has been hypothesized that black sagebrush ( $A$. nova) is preferred by mule deer over big sagebrush (Nagy and Tengerdy 1968; Dietz and Nagy 1976; and Nagy and Regelin 1977). The idea behind this hypothesis is that black sagebrush contains lower concentrations of monoterpenoids (essential or volatile oils) which are less inhibitory to microorganisms than big sagebrush. This would in theory cause the deer to select black sagebrush over big sagebrush. This hypothesis, however, does not take into account the observations made by Smith (1950) and Sheehy (1975) that mule deer did not prefer black sagebrush over big sagebrush, even though Sheehy (1975) found monoterpenoid content to be lower in black sagebrush than in big sagebrush. Our results somewhat support the observations of Smith (1950) and Sheehy (1975) (Table 4). From our study of mule deer preference for accessions of black sagebrush and that of Scholl et al. (1977) and Stevens and McArthur (1974), there appears, however, to be enough variation that some accessions of black sagebrush could be preferred over some accessions of big sagebrush and vis-a-vis. The proposed role of monoterpenoids in determining differential preference among species of Artemisia or accessions of Artemisia is questionable. Sheehy (1975) reported that the relative concentration of eight monoterpenoids could account for $90 \%$ of the variation of mule deer utilization among seven sagebrush taxa. Scholl et al. (1977), however, using the relative concentration of eight monoterpenoids, could only account for $20.7 \%$ of the variation of mule deer utilization among 12 sagebrush taxa. Radwan and Crouch (1978) found that the "families of Douglas-fir" varied significantly in yield 
and composition of essential oils, but differences were not related to preference (as determined by black-tailed deer). Welch and McArthur (1981) have reported significance in yield and composition of monoterpenoids among 21 accessions of big sagebrush, grown on the Ephraim, Utah, uniform garden. Unfortunately, wild mule deer do not move in this garden in high enough numbers to allow us to rank the accession according to preference. The 21 accessions, mentioned above, have been established on field plots on mule deer winter ranges. When the plants are ready, we will conduct preference tests and determine monoterpenoid levels. These two measurements will be related together as an aid in determining any adjustment we may need to make on our breeding and selecting program.

\section{Literature Cited}

Brunner, J.R. 1972. Observations on Artemisia in Nevada. J. Range Manage. 25:205-208.

Constan, K.J. 1972. Winter foods and range use of three species of ungulatcs. J. Wildl. Manage. 36:1068-1076.

Dietz, D.R., and J.G. Nagy. 1976. Mule deer nutrition and plant utilization. p. 71-78 In: Mule deer decline in the West-A symposium. G.W. Workman and J.B. Low (eds.). Utah State Univ., Coll. Natural Resour. Logan. 134 p.

Hanks, D.L., E.D. McArthur, R. Stevens, and A.P. Plummer. 1973. Chromatographic characteristics and phylogenetic relationships Artemisia section Tridentatae. U.S. Dep. Agr. Forest Serv. Res. Pap. INT-141, 24 p. Intermountain Forest and Range Exp. Sta., Ogden, Utah.

Julander, 0. 1955. Deer and cattle range relations in Utah. For. Sci. $1: 130-139$

Kufeld, R.C., O.C. Wallmo, and C. Feddema. 1973. Foods of the Rocky Mountain mule deer. U.S. Dep. Agr., Forest Serv. Res. Pap. RM-111, 31 p. Rocky Mountain Forest and Range Exp. Sta., Fort Collins, Colo.

Mackie, R.J. 1970. Range ecology and relations of mule deer, elk, and cattle in the Missouri River Breaks, Montana. Wildl. Monog. 20:1-79.

McArthur, E.D., A.C. Blauer, A.P. Plummer, and R. Stevens. 1979. Characteristics and hybridization of important intermountain shrubs. III. Sunflower family. U.S. Dep. Agr. Forest Serv. Res. Pap. INT-220, 82 p. Intermountain Forest and Range Exp. Sta., Ogden, Utah.

Medin, D.E., and A.E. Anderson. 1979. Modeling the dynamics of a Colorado mule deer population. Wildl. Monog. 68.

Medin, D.E. 1980. Unpublished data on file at the Shrub Sciences Laboratory, 735 North 500 East, Provo, Utah 84601.

Nagy, J.G., H.W. Steinhoff, and G.M. Ward. 1964. Effects of essential oils of sagebrush on deer rumen microbial function. J. Wild: Manage. 28:785-790.

Nagy, J.G., and R.P. Tengerdy. 1968. Antibacterial action of essential oils of Artemisia as an ecological factor. II. Antibacterial action of the volatile oils of Artemisia tridentata (big sagebrush) on bacteria from the rumen of mule deer. Appl. Microbiol. 16:441-444.

Nagy, J.G., and W.L. Regelin. 1977. Influence of plant volatile oils on feed selection by animals. XIIlth Congress of Game Biologists 13:225-230.

Nagy, J.G. 1979. Wildlife nutrition and the sagebrush ecosystem. p. 164168. In: The sagebrush ecosystem: A symposium. G.F. Gifford, F.E. Busby, and J.P. Shaw (eds.). Utah State Univ., Coll. Natural Resour., Logan.

National Academy of Sciences/National Research Council. 1962. Basic problems and techniques in range research. NAS/NRC Publ.890,34l p.

Plummer, A.P., D.R. Christensen, and S.B. Monsen. 1968. Restoring big game range in Utah. Utah Div. Wildl. Resour. Pub. 68-3, 183 p.

Radwan, M.A. and G.L. Crouch. 1978. Selected chemical constituents and deer browsing preference of Douglas fir. J. Chem. Ecol. 4:675-683.

Scholl, J.P., R.G. Kelsey, and F. Shafizadeh. 1977. Involvement of volatile compounds of Artemisia in browse preference by mule deer. Biochem. Sys. and Ecol. 5:291-295.

Sheehy, D.P. 1975. Relative palatability of seven Artemisia taxa to mule deer and sheep. M.S Thesis, Oregon State Univ., Corvallis. 147 p.

Smith, A.D. 1950. Sagebrush as winter feed for mule deer. J. Wildl. Managc. 14:285-289.

Snedecor, G.W., and W.G. Cochran. 1967. Statistical Methods. The lowa State Univ. Press, Ames. 593 p.

Stevens, R., and E.D. McArthur. 1974. A simple field technique for identification of some sagebrush taxa. J. Range Manage. 27:325-326.

Welch, B.L., and D. Andrus. 1977. Rose hips-a possible high-energy food for wintering mule deer? U.S. Dep. Agr. Forest Serv. Res. Note INT-221, 5 p. Intermountain For. and Range Exp. Sta., Ogden, Utah.

Welch, B.L., and E.D. McArthur. 1979a. Feasibility of improving big sagebrush (Artemisia tridentata) for use on mule deer winter ranges. In: Proc. international arid lands confer. plan resour. J.R. Goodin and D.K. Northington (eds.). Texas Tech. Univ., Lubbock. 724 p.

Welch, B.L., and E.D. McArthur. 1979b. Variation in winter levels of crude protein among Artemisia tridentata subspecies grown in a uniform garden. J. Range Manage. 32:467-469.

Welch, B.L., and E.D. McArthur. 1981. Variation of monoterpenoid content among subspecies and accessions of Artemisia tridentata grown in a uniform garden. J. Range Manage. 34:380-384.

Welch, B.L., and J.C. Pederson. 1982. In vitro digestibility among accessions of big sagebrush by wild mule deer and its relationship to monoterpenoid content. J. Range manage. 35: In press.

Willms, W., A. McLean, R. Tucker, and R. Ritcey. 1979. Interactions between mule deer and cattle on big sagebrush range in British Columbia. J. Range Manage. 32:299-304.

Winward, A.H. 1970. Taxonomic and ecological relationships of the big sagebrush complex in Idaho. Ph.D. Diss. Univ. Idaho, Moscow. 80 p.

Winward, A.H., and E.W. Tisdale. 1977. Taxonomy of the Artemisia tridentata complex in Idaho. Coll. Forest, Wildl. and Range Sci., Univ. Idaho, Moscow. Bull. 19, 15 p.

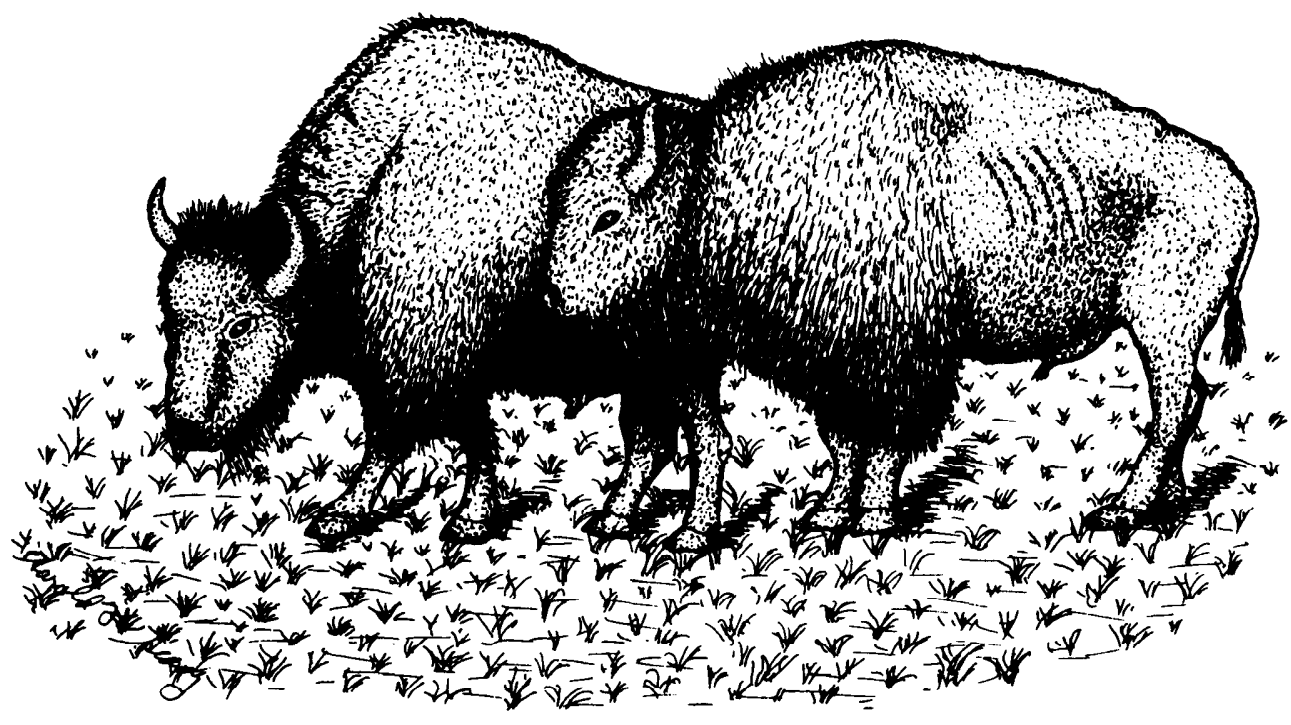

